\title{
Report on the Water Surface Extent of Lakes in the Central Rift Valley of Ethiopia
}

\author{
Nesru Hassen* and Nesibu Yahya \\ Ethiopian Environment and Forestry Research Institute, Ethiopia
}

Submission: September 11, 2019; Published: October 02, 2019

*Corresponding author: Nesru Hassen, Ethiopian Environment and Forestry Research Institute, P. O. Box 33042 code 1000, Addis Ababa, Ethiopia

\section{Abstract}

Lakes are one of the most important biologically diverse ecosystems. However, extensive human and natural factors contributed to the loss of this ecosystem. Until recently, knowledge on the recent status of rift valley lakes was lacking. Therefore, the aim of this study was to estimate the current extent of selected lakes in the central Rift Valley of Ethiopia using Landsat image. Satellite images of Landsat OLI_TIRS for the year 2018 used for this study. Selected bands (green, near infrared, shortwave infrared and middle infrared) were selected in calculating automated water extraction index to distinguish water surface from non-water. The result revealed that the extent of water surface reduced between 2015 and 2018 with an amount of 47.6, 2.4 and $0.9 \%$ for Lake Abate, Shala and Longino, respectively. Such rapid conversions of aquatic ecosystem need urgent management and policy intervention. Furthermore, applied researches must needed to reduce the magnitude of change.

Keywords: Landsat; Shala; Langano; Abjata

\section{Introduction}

Aquatic and wetland are among the most biologically diverse ecosystems, which provide multiple ecosystem services in the world. Besides the significance, it is also one of the most susceptible ecosystems $\mathrm{Hu}$ et al. [1]. The extents of these ecosystems are declining through time in both quality and quantity. In the 20th century, the size of global wetlands was declined between 64 and $71 \%$, and it is a cause for the estimated loss of US $\$ 20$ trillion of services from ecosystem each year Gardner et al. [2].

In the Ethiopian rift valley, where most lakes are available, lakes play a key role in providing many socio-economic values such as fisheries, grazing and recreation. The majority of lakes are vulnerable to anthropogenic pressure and some are already lost (e.g. Lake Haromaya) due to over-exploitation and mismanagement of their catchment Meshesha et al. [3], Lemma \& Desta [4]. Therefore, a continues inventory and monitoring of their extent using remote sensing is highly needed Ozesmi \& Bauer [5]. Incidentally, various reports were provided on the extent of lakes in the earlier works Ariti et al. [6], Tibebu Kassawmar et al. [7], Sisay [8]. These works, however, give information earlier than 2015. Until recently, knowledge on the recent status of rift valley lakes was lacking, despite the fact that they rapidly changing over time. Therefore, this study aims to estimate the current extent of selected lakes in the central Rift Valley of Ethiopia using Landsat image.

\section{Material and Methods}

\section{Study area}

This study conducted on the three rift valley lakes in Ethiopia namely Shala, Abjata and Langone. The study area is part of the Great Rift Valley zone, which extends from southwestern to northeast direction. The location of the study area is lies between $7^{\circ} 20^{\prime}$ to $7^{\circ} 50^{\prime \prime} \mathrm{N}$ latitude and between $38^{\circ} 20^{\prime \prime}$ to $38^{\circ} 50^{\prime \prime} \mathrm{E}$ longitude (Figure 1).

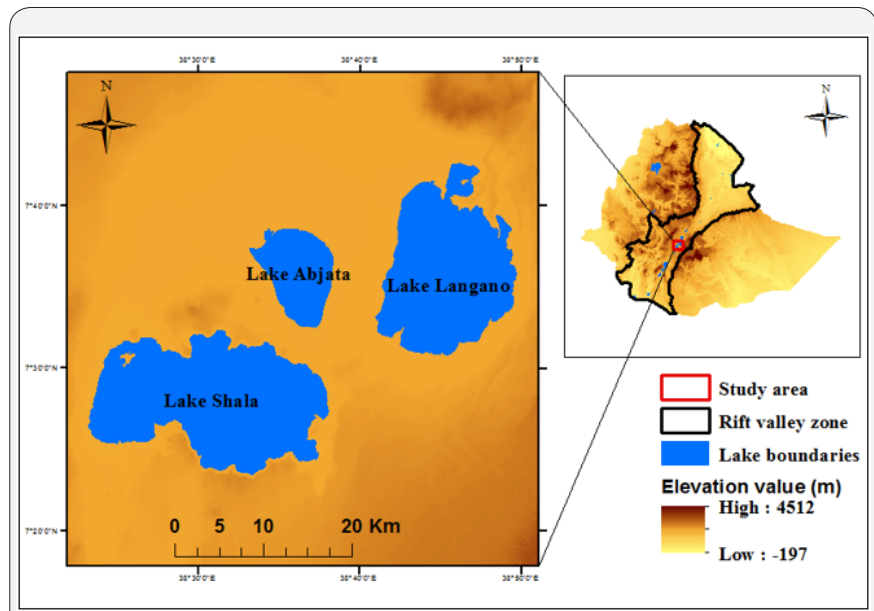

Figure 1: Location map of selected Lakes in the central rift valley.

\section{Data acquisition and analysis}

The single scene of Landsat image (path=168, raw=055) was downloaded from the archive of the United States Geological Survey (USGS). The acquisition date of the downloaded image was January 29, 2018 (dry season). After the image is procured, image-preprocessing techniques (both radiometric and geometric) were implemented for each selected bands of the image. The spectral bands of the satellite image covering the green (Band 3), near infrared (Band 5), shortwave infrared (Band 
6) and Middle infrared (Band 7) were selected for analysis. In addition, the original digital number (DN) value of selected bands was converted to radiance and then into atmospheric reflectance using the following equations.

$L \lambda=((L M A X \lambda-L M I N \lambda) /(Q C A L M A X-Q C A L M I N)) *(Q C A L-Q C A L M I N)+$ LMIN $\lambda$

Where

$L \lambda=$ Spectral radiance at the sensor's aperture in watts/ (meter squared $*$ ster $* \mu \mathrm{m})$.

$Q C A L=$ the quantized calibrated pixel value in DN .

LMIN $\lambda=$ the spectral radiance that is scaled to QCALMIN in watts/ (meter squared ${ }^{*}$ ster $\left.^{*} \mu \mathrm{m}\right)$.

$L M A X \lambda=$ the spectral radiance that is scaled to QCALMAX in watts/ (meter squared ${ }^{*}$ ster $\left.^{*} \mu \mathrm{m}\right)$.

QCALMIN = the minimum quantized calibrated pixel value (corresponding to $L M I N \lambda$ ) in DN $=1$ for LPGS. products $=1$ for NLAPS products processed after $4 / 4 / 2004=0$ for NLAPS products processed before 4/5/2004.

QCALMAX = the maximum quantized calibrated pixel value (corresponding to $L M A X \lambda$ ) in $\mathrm{DN}=255$.

$$
R F=\pi * L \lambda * D 2 / E S U N \lambda * \cos \theta S
$$

Where

$R F=$ unit less planetary reflectance.

$L \lambda=$ Spectral Radiance at the sensor's aperture in watts/ (meter squared $*$ ster $* \mu \mathrm{m})$.
$\mathrm{D}=$ Earth-Sun distance in astronomical unit.

ESUN $\lambda=$ mean solar exoatmospheric irradiances.

$\theta S=$ solar zenith angle.

Following the pre-processing activity, the bands were used to calculate Automated Water Extraction Index (AWEI). The index is one of the best methods to extract water surface from the image [9]. The positive value of this index indicates water surface, while a negative value is for the non-water surface.

$A W E I=4 *($ Green $-M I R)-(0.25 \times N I R+2.75 \times$ SWIR $)$

Where

AWEI= Automated Water Extraction Index.

Green= spectral band covering green spectrum.

$\mathrm{MIR}=$ spectral band covering middle infrared.

NIR= spectral band covering near infrared .

SWIR= spectral band covering shortwave infrared.

\section{Result and Discussions}

The extent of the water surface in 2018 shows that 69.15 , 297.89 and $227.90 \mathrm{Km}^{2}$ for Abate, Shala and Longino respectively. Within three years (2015-2018), the water surface extents of all selected lakes were reduced at various magnitudes ranging from $2.1 \mathrm{Km}^{2}$ to $62.8 \mathrm{Km}^{2}$. The water surface extent of Lake Abjata has lost $62.8 \mathrm{Km}^{2}(47.6 \%)$, which is a considerable area compared with the other two lakes. Between 2015-2018, the extent of Lake Shala reduces in a size of $7.3 \mathrm{Km}^{2}$ followed by Lake Longino in a size of $2.1 \mathrm{~km}^{2}$ (Figure 2).

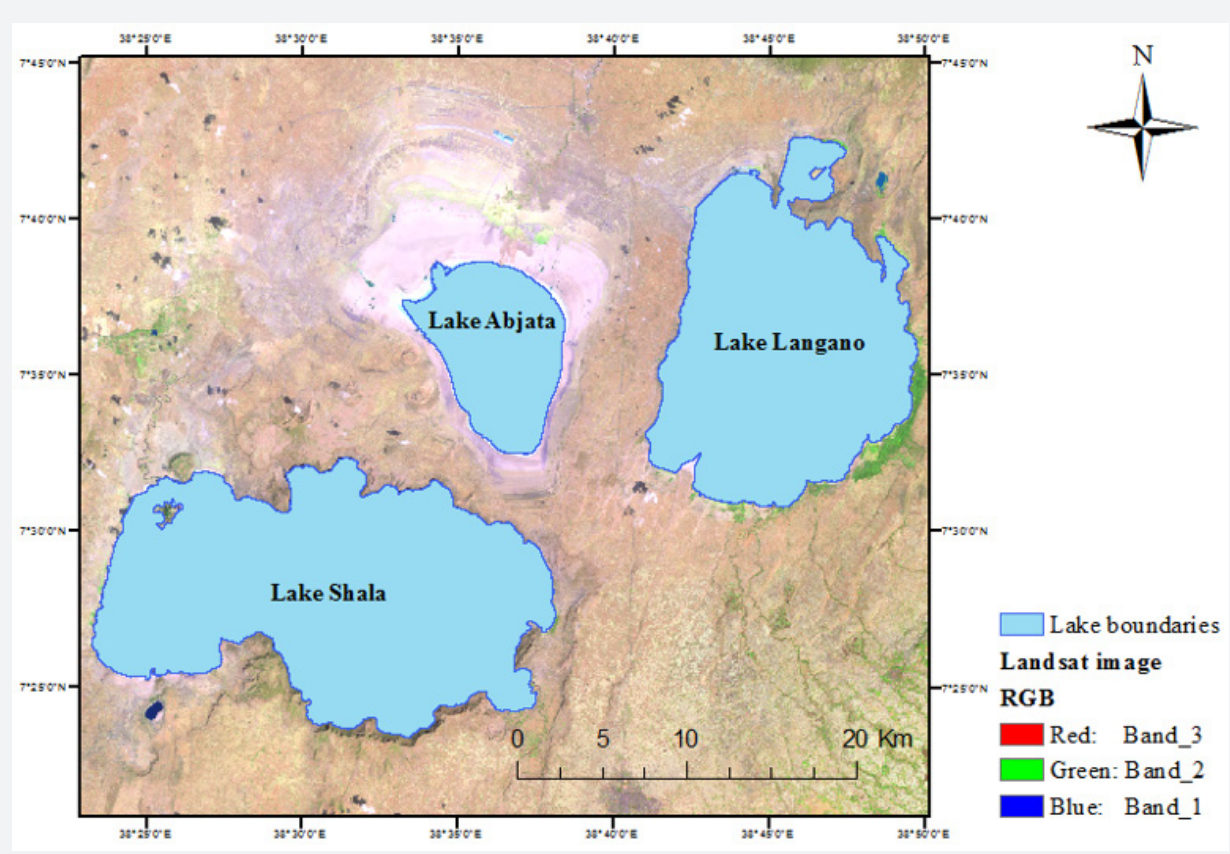

Figure 2: Map of selected lakes in central rift valley zone of Ethiopia. 
Table1: Extent of selected lakes from central rift valley area of Ethiopia.

\begin{tabular}{|c|c|c|c|c|c|c|c|c|c|}
\hline \multirow{2}{*}{$\begin{array}{l}\text { Study } \\
\text { Years }\end{array}$} & \multicolumn{3}{|c|}{ Abjata } & \multicolumn{3}{|c|}{ Shala } & \multicolumn{3}{|c|}{ Langano } \\
\hline & $\begin{array}{l}\text { Extent } \\
\left(\mathbf{k m}^{2}\right)\end{array}$ & $\begin{array}{c}\text { Extent } \\
\text { Change }\left(\mathrm{km}^{2}\right)\end{array}$ & Change (\%) & $\begin{array}{l}\text { Extent } \\
\left(\mathbf{k m}^{2}\right)\end{array}$ & $\begin{array}{c}\text { Extent Change } \\
\left(\mathrm{km}^{2}\right)\end{array}$ & Change (\%) & $\begin{array}{l}\text { Extent } \\
\left(\mathbf{k m}^{2}\right)\end{array}$ & $\begin{array}{c}\text { Extent Change } \\
\left(\mathbf{k m}^{2}\right)\end{array}$ & Change (\%) \\
\hline $1973^{*}$ & 200.13 & - & - & 315.36 & - & - & 233.68 & - & - \\
\hline $1986^{*}$ & 165.22 & -34.92 & -17.45 & 309.84 & -5.53 & -1.75 & 231.39 & -2.3 & -0.98 \\
\hline $2000^{*}$ & 164.83 & -0.39 & -0.24 & 307.97 & -1.87 & -0.6 & 231.46 & 0.07 & 0.03 \\
\hline $2005^{*}$ & 94.69 & -70.13 & -42.55 & 306.2 & -1.77 & -0.57 & 230.23 & -1.22 & 0.53 \\
\hline $2011^{*}$ & 128.01 & 33.32 & 35.18 & 306.47 & 0.27 & 0.09 & 231.51 & 1.28 & 0.56 \\
\hline $2015^{*}$ & 131.94 & 3.93 & 3.07 & 305.16 & -1.32 & 0.43 & 230.01 & -1.51 & 0.65 \\
\hline $2018^{* *}$ & 69.15 & -62.79 & -47.59 & 297.89 & -7.27 & -2.38 & 227.9 & -2.11 & -0.92 \\
\hline
\end{tabular}

*The water surface extent of the three lakes from Sisay [11].

**The water surface extent from the present study.

In many previous works, the extent of some rift valley lakes shows a reducing trend over time (Table 1). Lake Abjata lost $46 \%$ of its area between 2000 and 2006 Temesgen et al. [10]. This result is comparable with the reduction magnitude (42.6\%) obtained by [8] between 2000 and 2005. Between 2000 and 2014, the area of the two lakes (Abjata and Langano) jointly declined by $9 \%$ Ariti et al. [6]. Certainly, Lake Langano and Lake Shala experienced only small amount of changes over the last three decades (Table 1). The extent of Abaya and Chamo (the other rift valley lakes) were reduced, significantly, between 1986 and 2000 Tibebu Kassawmar et al. [7].

In general, several factors may contribute to the reduction of water surface. Pumping high amount of water for the production of Soda Ash was reported as one of the major responsible factors for the rapid decline of Lake Abjata Legesse \& Ayenew [11]. Land use change on the catchment was one of the major factors for the loss of Lake Haromaya in Eastern Ethiopia Meshesha et al. [3]. Reversely, land use change of the surrounding watershed that drives high surface run-off increase the level of water in Lake Awassa and Beseka Dinka [12], Nigatu Wondrade et al. [13].

\section{Conclusion and Recommendation}

The results of this study have shown that the extent of the water surface of Lake Abjata was considerably reduced (47.6\%) between 2015 and 2018. In this study period, Lake Shala and Lake Langano reduced with a magnitude of 2.4 and $0.9 \%$, respectively. Such rapid changes, particularly on Lake Abjata, need an urgent management intervention as a short-term solution and it requires developing policy and strategy for aquatic and wetland ecosystem as a long-term solution. In addition, applied research should carried out to reduce the magnitude of change.

\section{Acknowledgement}

The author would like to thank anonymous reviewers for their valuable and constructive comments to enrich the manuscript.

\section{References}

1. Hu S, Niu Z, Chen Y, Li L, Zhang H (2017) Global wetlands: Potential distribution, wetland loss, and status. Sci Total Environ 586: 319-327.

2. Gardner RC, Barchiesi S, Beltrame C, Finlayson CM, Galewski T, et al. (2015) State of the World's Wetlands and Their Services to People: A Compilation of Recent Analyses. SSRN: 21.

3. Meshesha DT, Tsunekawa A, Tsubo, Ali SA, Haregeweyn N (2014) Landuse change and its socio-environmental impact in Eastern Ethiopia's highland. Regional Environmental Change 14(2): 757-768.

4. Lemma B, Desta H (2016) Review of the natural conditions and anthropogenic threats to the Ethiopian Rift Valley rivers and lakes. Lakes \& Reservoirs: Research \& Management 21(2): 133-151.

5. Ozesmi SL, Bauer ME (2002) Satellite remote sensing of wetlands. Wetlands Ecology and Management 10(5): 381-402.

6. Ariti AT, Van Vliet J, Verburg PH (2015) Land-use and land-cover changes in the Central Rift Valley of Ethiopia: Assessment of perception and adaptation of stakeholders. Applied Geography 65: 28-37.

7. Tibebu KN, Ram Mohan RK, Lemlem AG (2011) An integrated approach for spatio-temporal variability analysis of wetlands: a case study of Abaya and Chamo lakes, Ethiopia. Environ Monit Assess 180(1-4): 313-324.

8. Sisay A (2016) Remote Sensing Based Water Surface Extraction and Change Detection in the Central Rift Valley Region of Ethiopia. American Journal of Geographic Information System 5(2): 33-39.

9. Feyisa GL, Meilby H, Fensholt R, Proud SR (2014) Automated Water Extraction Index: A new technique for surface water mapping using Landsat imagery. Remote Sensing of Environment 140: 23-35.

10. Temesgen H, Nyssen J, Zenebe A, Haregeweyn N, Kindu M, et al. (2013) Ecological succession and land use changes in a lake retreat area (Main Ethiopian Rift Valley). Journal of Arid Environment 91: 53-60.

11. Legesse D, Ayenew T (2006) Effect of improper water and land resource utilization on the central Main Ethiopian Rift lakes. Quat Int 148(1): 8-18.

12. Dinka MO (2012) Analysing decadal land use/cover dynamics of the Lake Basaka catchment (Main Ethiopian Rift) using LANDSAT imagery and GIS. Lakes \& Reservoirs: Research \& Management 17: 11-24.

13. Nigatu W, Dick ØB, Tveite H (2014) GIS based mapping of land cover changes utilizing multi-temporal remotely sensed image data in Lake Hawassa Watershed, Ethiopia. Environ Monit Assess 186(3): 17651780. 
DOI: $10.19080 / I J E S N R .2019 .21 .556071$

Your next submission with Juniper Publishers will reach you the below assets

- Quality Editorial service

- Swift Peer Review

- Reprints availability

- E-prints Service

- Manuscript Podcast for convenient understanding

- Global attainment for your research

- Manuscript accessibility in different formats (Pdf, E-pub, Full Text, Audio)

- Unceasing customer service

Track the below URL for one-step submission https://juniperpublishers.com/online-submission.php 